\title{
Chitinase and cellulase activity from Bacillus thuringiensis strains
}

\author{
Vinícius Fiúza Dumas ${ }^{1}$ \\ Clarissa dos S. Goldenberg ${ }^{2}$ \\ Érica Soares Martins ${ }^{3}$ \\ Lílian Botelho Praça ${ }^{4}$ \\ Paulo Roberto Queiroz ${ }^{5}$ \\ Rose Gomes Monnerat ${ }^{6}$ \\ Francislete Rodrigues Melo ${ }^{7}$
}

\begin{abstract}
The present study aimed to analyze the production of chitinase and cellulase enzymes by strains of Bacillus thuringiensis toxic to Spodoptera frugiperda and Anthonomus grandis larvae. In order to evaluate the relationship between cellular growth and the chitinase and cellulase production, in vitro assays were carried through with bacteria cultures grown for $16 \mathrm{~h}, 24 \mathrm{~h}, 48 \mathrm{~h}$ and $72 \mathrm{~h}$. Chitinase and cellulase activity was determined by a colorimetric method. The amount of $\mathrm{N}$-acetylglucosamine (GlcNAc) or its equivalent was measured by development of color in acid medium. All strains presented enzymatic production after $16 \mathrm{~h}$ of cellular growth until $72 \mathrm{~h}$. However, a Kruskal-Wallis test detected no significant differences among the chitinase and cellulase activity during the cellular growth. According to these results, was not possible to associate chitinase and cellulose activity with the different level of toxicity of $B t$ strains against $S$. frugiperda and $A$. grandis larvae.
\end{abstract}

Keywords: Bacillus thuringiensis. Chitinase. Cellulase. Cry proteins.

\footnotetext{
${ }^{1}$ MSc. Biologia Molecular. Universidade de Brasília - UnB; e-mail: vfdumas@yahoo.com.br. ${ }^{2}$ BSC Ciências Agrárias. Universidade de Brasília - UnB.

${ }^{3}$ PhD Biologia Molecular. Universidade de Brasília - UnB; e-mail: erica_martins@pop.com.br

${ }^{4}$ MSc. Agronomia. Universidade de Brasília - UnB. Assistente do Centro Nacional de Recursos Genéticos, EMBRAPA; e-mail: lílian@cenargen.embrapa.br

${ }^{5} \mathrm{PhD}$ Biologia Animal. Universidade de Brasília - UnB. Professor do curso de Biologia UniCEUB; e-mail: pqsilva@uol.com.br

${ }^{6} \mathrm{PhD}$ Agronomia. Ecole Nacionale Agronomique de Montpellier. Pesquisadora do Centro Nacional de Recursos Genéticos, EMBRAPA; e-mail: rose@ cenargen.embrapa.br

7 PhD Biologia Molecular. Universidade de Brasília - UnB. Professora UPIS; e-mail: etemelo@gmail.com
} 


\section{Introduction}

Several organisms produce a wide variety of hydrolytic enzymes actives against different substrate, such as chitin and cellulose. Chitinases could be produced by plants, insects and microorganisms as Bacillus licheniformis and Bacillus Pakistani (GOODAY, 1995). In bacteria, chitinases could be used in nutrition and parasitism whereas in fungi and vertebrates they are also involved in morphogenesis (PATIL et. al., 2000). Different chitinases secreted in culture medium by $\mathrm{Ba}$ cillus circulans showed strong affinity to insoluble chitin and presented a C-terminal chitin-binding domain and the $\mathrm{N}$-terminal large domain containing catalytic site (WATANABE, 1993). Enzymatic hydrolysis of chitin to free $\mathrm{N}$-acetylglucosamine (GlcNAc) is conduced by a chitinolytic system synergistic and consecutive (DESHPANDE, 1986; SHAIKH et. al., 1993).

Some bacteria, additionally, produce cellulases. The widely accepted mechanism for this enzyme hydrolysis involves synergistic actions by endoglucanase, exoglucanase or cellobiohydrolase and $\beta$-glucosidase (KNOWLES et al., 1987; WOOD; GARCIA-CAMPAYO, 1990; HENRISSAT, 1994; TEERI, 1997, LYND et al., 2002; ZHANG; LYND, 2004). During cellulose hydrolysis, the substrate characteristics vary, including changes in the cellulose chain end number resulting from generation by endoglucanases and consumption by exoglucanases (KLEMANLEYER et al., 1992, 1994, 1996; KONGRUANG et al., 2004). Also could be observed changes in cellulose accessibility resulting from substrate consumption and cellulose fragmentation (BANKA et al., 1998; BOISSET et al., 2000; WANG et al., 2003).

Among bacteria, Bacillus species produce a variety of extracelcellular polysaccharide hydrolysing enzymes (PRIEST, 1977). Cellulases produced by Bacillus strains were isolated and purified showing 100\% homology with endoglucanases from Bacillus subtilis belonging to glycoside hydrolase family five (MAWADZA et al., 2000). In addition, some entomopathogenic bacteria have been used as an alternative to insect control (MONNERAT; BRAVO, 2000). Bacillus thuringiensis $(B t)$ is a gram-positive soil bacteria, during sporulation form a parasporal crystal containing insecticidal proteins called Cry proteins or $\delta$-endotoxins (MAAGD et al., 2003). These insecticidal crystal proteins ingested by the insect are submitted to site-specific proteolysis to generate active fragments that bind to the receptors in 
the midgut epithelium and form ion channels, inducing osmotic lysis of the epithelium that consequently kills the larvae (LORENCE et al., 1995). The midgut lumen is separated from the epithelium by a protective structure consisting of chitin and proteins, called peritrophic membrane (TERRA, 2001). It is believed that chitinases disrupt the integrity of these membranes, facilitating the contact between the activated toxins Cry and receptors in the midgut epithelium (REGEV et al., 1996). Thus, a synergistic action between Cry toxins and chitinases has been demonstrated to occur during co-application of insecticidal protein containing spore suspension and chitinase (SMIRNOFF, 1977).

Here, we report the chitinase and cellulase activity from $B$. thuringiensis strains effective toxic to the fall armyworm Spodoptera frugiperda and cotton bowl weevil, Anthonomus grandis (MARTINS et al., 2007; MONNERAT et al., 2007). These insects are pest of economic importance for basic grain production in the Americas (ASHLEY et al., 1989; PORTILLO et al., 1991).

The aim of this study was to analyze the production of chitinase and cellulase enzymes by strains of Bacillus thuringiensis toxic to Spodoptera frugiperda and Anthonomus grandis larvae.

\section{Materials and methods}

\section{Bacterial strains}

Strains from B. thuringiensis denominated S601, S1806, S906, S907, S908, and $B$. thuringiensis tenebrionis (Btt), toxic against $A$. grandis larvae (MARTINS et al., 2007) and the strains S550, S845, S1905 and Bacillus thuringiensis kurstaki (Btk), actives against $S$. frugiperda larvae (MONNERAT et al., 2007) were obtained from collection of Entomopathogenic Bacillus spp. Bank, of Embrapa Recursos Genéticos e Biotecnologia, except to $B t k$ and $B t t$ strains, that were obtained from the collection of Bacillus thuringiensis and Bacillus sphaericus at the Institut Pasteur, Paris.

\section{Chitinase enzymatic assays}

The assays were done at Laboratory of Entomopathogenic Bacteria - Embrapa Recursos Genéticos e Biotecnologia, using bacterial cultures to compare the chitinase production at various stages of cell growth $(16,24,48$ and $72 \mathrm{~h})$. The 
4 Universitas: Ciências da Saúde, Brasília, v. 7, n. 1, p. 1-12, 2009

Vinícius F. Dumas, Clarissa S. Goldenberg, Érica S. Martins, Lílian B. Praça,

Paulo R. Queiroz, Rose G. Monnerat, Francislete R. Melo

strains active against $A$. grandis and the strains active against $S$. frugiperda were grown in NYSM medium (YOUSTEN, 1984) without addition of colloidal chitin at $28{ }^{\circ} \mathrm{C}$ and $200 \mathrm{rpm}$ in a rotating shaker. Chitinase activity was determined by a colorimetric method, conduced according to Reissig et al. (1955). For each test, $300 \mu \mathrm{L}$ sample of the different bacterial cultures were reacted with $500 \mu \mathrm{L}$ of $0,5 \%$ colloidal chitin in $50 \mathrm{nM}$ acetate buffer ( $\mathrm{pH}$ 5.0). A blank was prepared without chitin and the assay was performed at $37^{\circ} \mathrm{C}$. The amount of $\mathrm{N}$-acetylglucosamine (GlcNAc) or its equivalent was measured by development of color in acid medium using DNS (dinitrosalicylic acid). Absorbance was determined at $550 \mathrm{~nm}$ and one unit activity (UA) was defined as the amount of enzyme necessary for produce an absorbance of 0,100. (HOFTE et al., 1987). The assays were repeated three time and the results were compared by ANOVA through Sigma stat program (KUO et al., 1992).

\section{Cellulase enzymatic assays}

The assays were carry out at Laboratory of Entomopathogenic Bacteria Embrapa Recursos Genéticos e Biotecnologia, using bacterial cultures to compare the cellulase production at various stages of cell growth $(16,24,48$ and $72 \mathrm{~h})$. The strains active against $A$. grandis and the strains active against $S$. frugiperda were also used, as in the chitinase assays. This assay was based on the determination of endoglucanases, exoglucanases and $\beta$-D-glucosidases, all of which hydrolyze cellulose synergically. The reaction contained $250 \mu$ Lculture cells, pure cellulosic substrate (Whatman No. 1 filter paper $1 \times 4 \mathrm{~cm}$ ) and $500 \mu$ Lof $50 \mathrm{mM}$ sodium citrate buffer, $\mathrm{pH}$ 4.5. Also, the blank was prepared by reacting $500 \mu$ Lof sodium citrate buffer with $250 \mu \mathrm{L}$ of bacterial culture, without cellulosic substrate. After incubation at $50^{\circ} \mathrm{C}$ for 60 minutes, the reaction was stopped by addition of $1,5 \mathrm{~mL}$ of dinitrosalicylic acid (DNS). The tubes were placed in a boiling- water bath for $5 \mathrm{~min}$. Absorbance was determined at $550 \mathrm{~nm}$ and one unit activity (UA) was defined as the amount of enzyme necessary for produce an absorbance of 0,100 (HOFTE et al., 1987). The assays were repeated three time and the results were compared by ANOVA through Sigma stat program (KUO et al., 1992). 


\section{Results and discussion}

The chitinase activity at different growth time was observed for all strains tested against $A$. grandis (Figure 1) and S. frugiperda (Figure 2) since $16 \mathrm{~h}$ until $72 \mathrm{~h}$. This result is according to other authors, who determined chitinase activity in different $B t$ strains (SAMPSON; GOODWAY, 1998; THAMTHIANKUL et al., 2001; SIRICHOTPAKORN et al., 2001).

Figure 1 - Chitinase activity of different Bt strains toxic to A. grandis larvae between $16 \mathrm{~h}$ and 72 h growth. A: Strain S906, B: Strain S907, C: strain S908, D: S601, E: strain S1806, F: strain Btt.
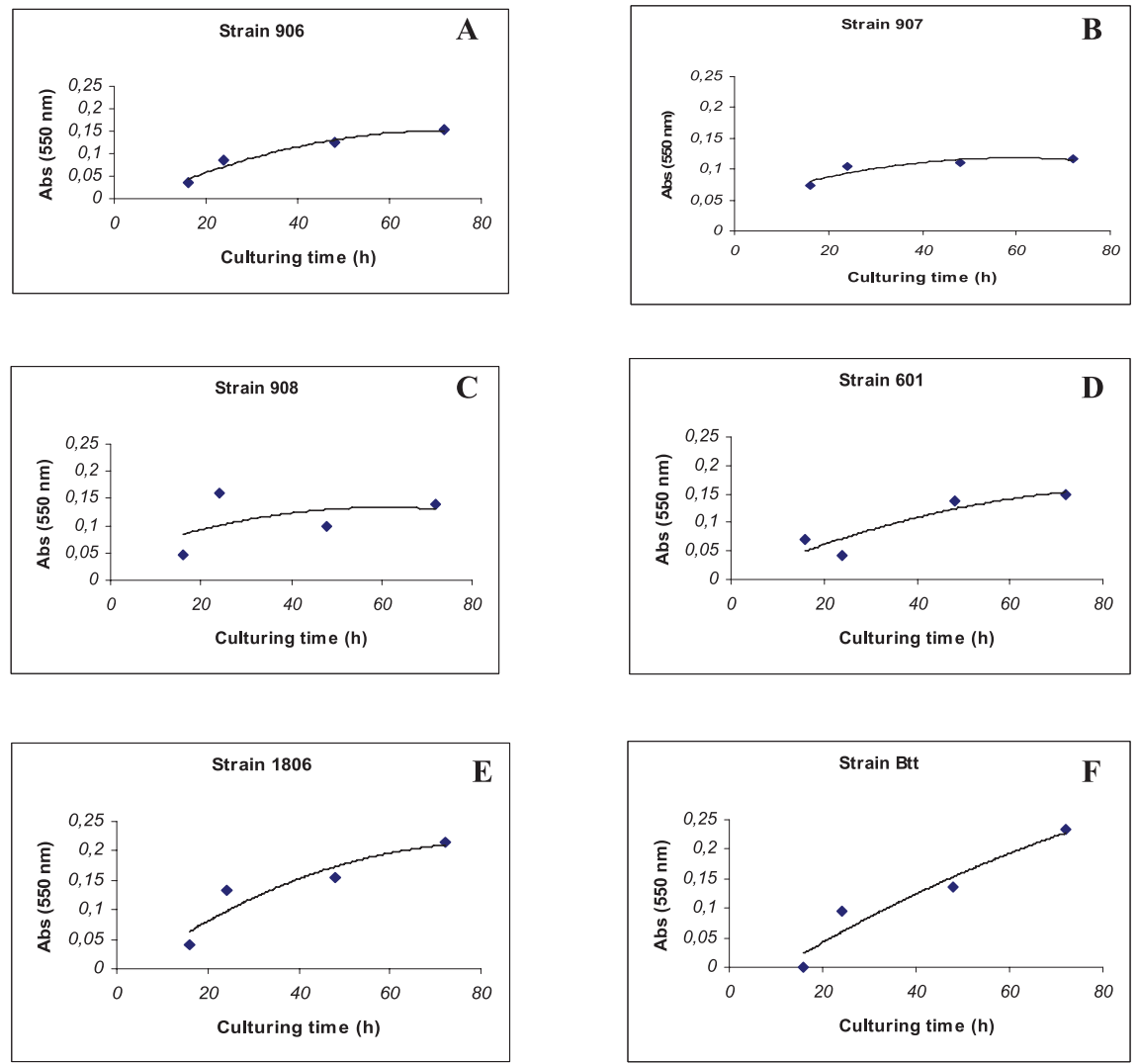
Figure 2 - Chitinase activity of different Bt strains toxic to $S$. frugiperda larvae between $16 \mathrm{~h}$ and 72 h growth. A: Strain S550, B: Strain S845, C: strain S1905, D: Btk.
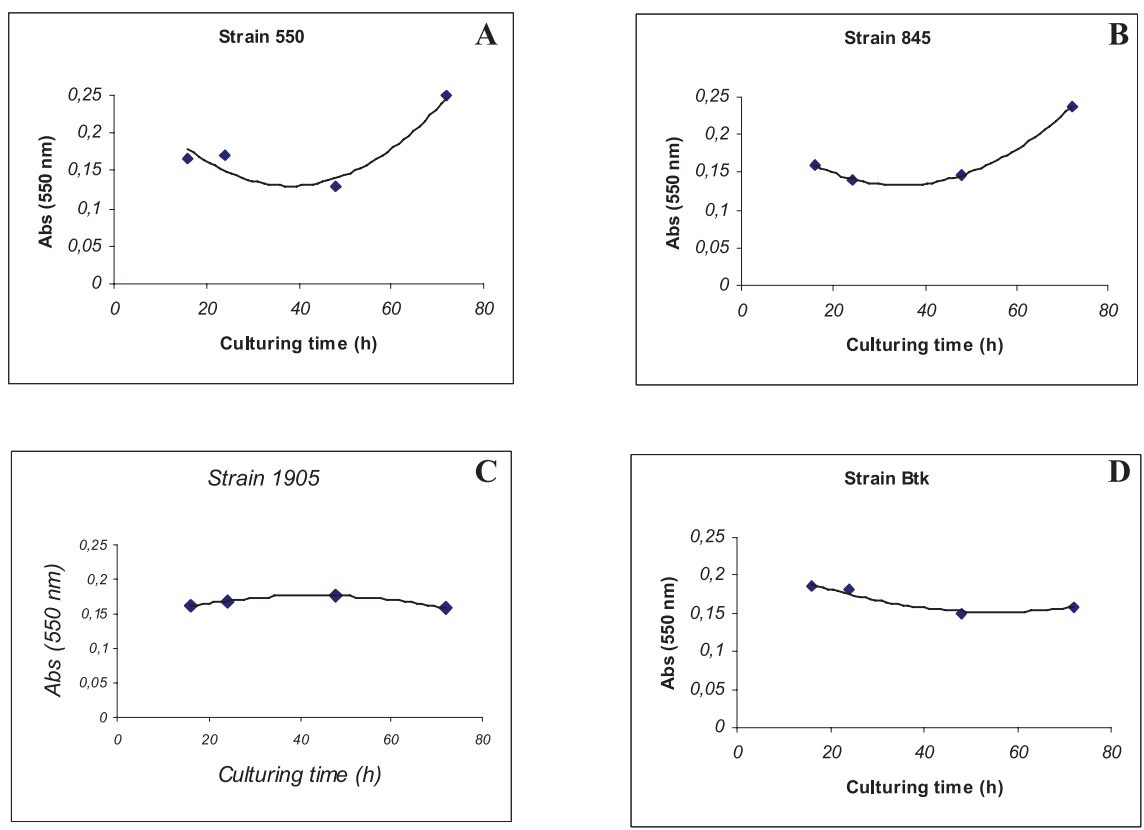

It is believed that chitinases disrupt the integrity of the peritrophic membranes in midgut lumen of several larvae insects, facilitating the contact between the activated toxins Cry and receptors in the midgut epithelium (REGEV et al., 1996). Thus, a synergistic action between Cry toxins and chitinases has been demonstrated to occur during co-application of insecticidal protein containing spore suspension and chitinase (SMIRNOFF, 1977). A Kruskal-Wallis test detected no significant differences among these chitinase activities enzymatic values from all strains tested (nonparametric analogous of SNK test, $P=0,012$ ), which were not statistically different from each other.

All strains toxic to A. grandis (Figure 3) and S. frugiperda (Figure 4) showed cellulase activity between $16 \mathrm{~h}$ and $72 \mathrm{~h}$ of cellular growth. Also was possible to observe some variation in cellulase activity between the different $B t$ strains analyzed, however, a Kruskal-Wallis test no detected significant differences among the cellulase activity enzymatic values from all strains tested (nonparametric analogous of 
SNK test, $P=0,004)$, which were not statistically different from each other. On the other hand, we observed the cellulose activity until $72 \mathrm{~h}$ of growth, when the majority of cell is in spore form.

Figure 3 - Cellulase activity of different Bt strains toxic to A. grandis larvae between $16 \mathrm{~h}$ and 72 h growth. A: Strain S906, B: Strain S907, C: strain S908, D: S601, E: strain S1806, F: strain Btt.
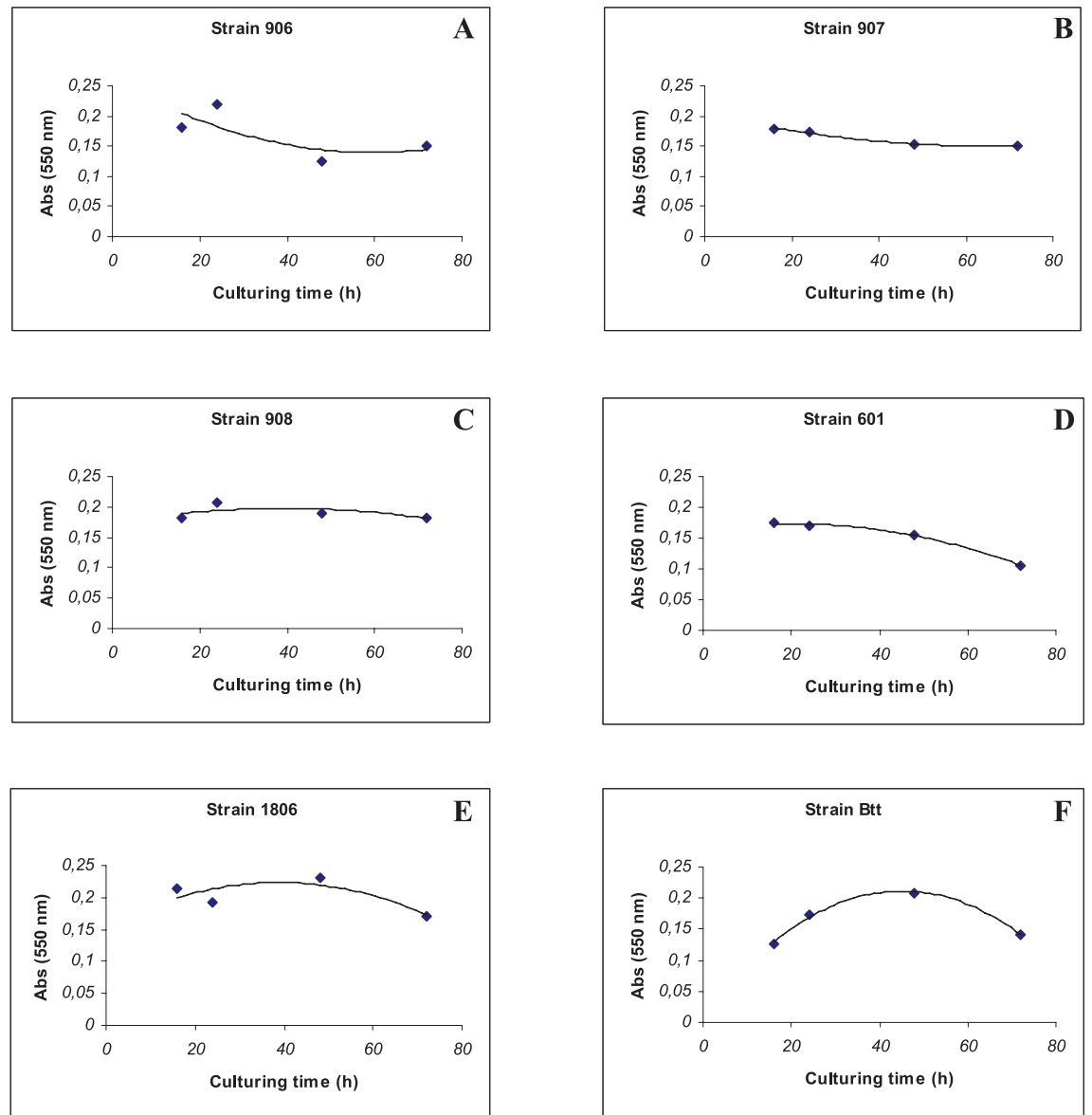
Figure 4 - Cellulase activity of different Bt strains toxic to $S$. frugiperda larvae between $16 \mathrm{~h}$ and 72 h growth. A: Strain S550, B: Strain S845, C: strain S1905, D: Btk.
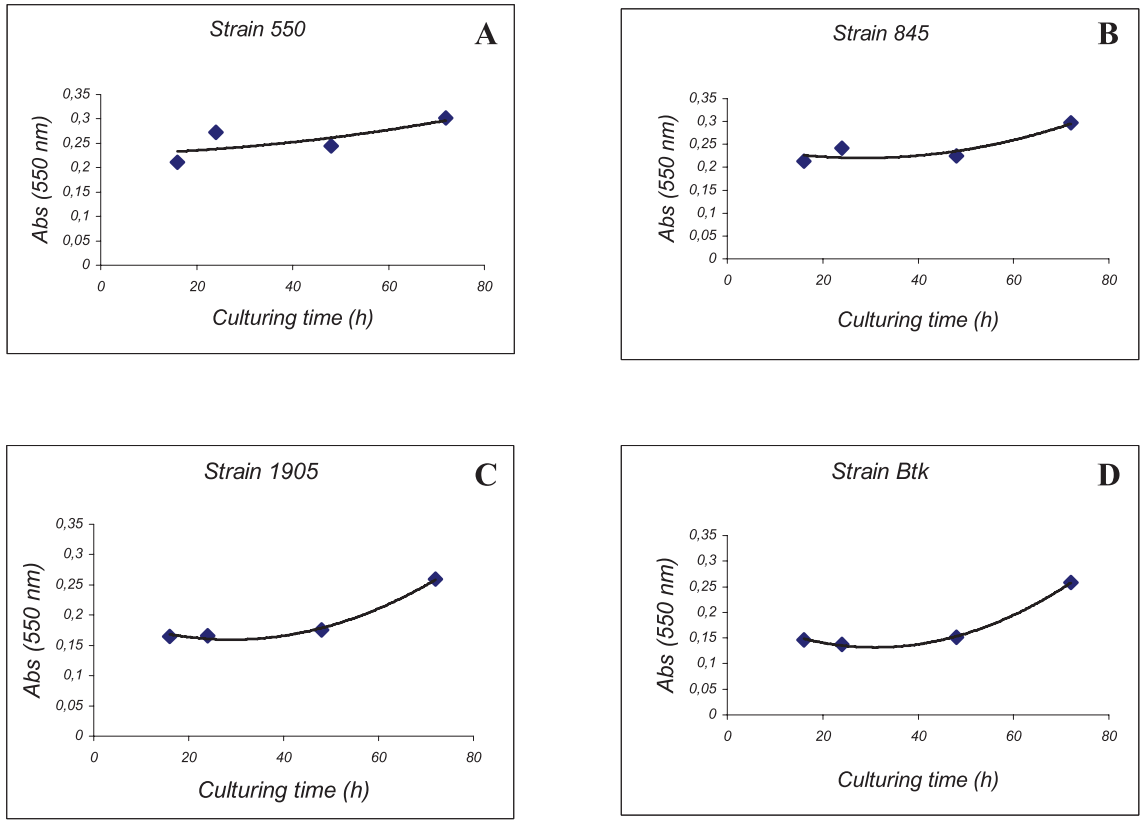

\section{Atividade quitinolítica e celulolítica de estirpes de Bacillus thuringiensis}

\section{Resumo}

O presente estudo buscou analisar a produção das enzimas quitinase e celulase produzidas por estirpes de Bacillus thuringiensis tóxicas a larvas de Spodoptera frugiperda e Anthonomus grandis. Para avaliar a relação do crescimento celular e a produção de quitinase e celulase foram feitos ensaios in vitro com culturas de bactérias crescidas por 16h, 24h, $48 \mathrm{~h}$ e $72 \mathrm{~h}$. A atividade quitinolítica e celulolítica foi determinada por método colorimétrico. A quantidade de $\mathrm{N}$-acetylglucosamine (GlcNAc) ou seu equivalente foi medido pelo desenvolvimento de coloração em meio ácido. Todas as linhagens apresentaram produção de enzimas após $16 \mathrm{~h}$ de crescimento celular até 72h. O teste de Kruskal-Wallis não detectou diferenças significativas entre as atividades quitinolítica e celulolítica durante o crescimento celular.

Palavras-chave: Bacillus thuringiensis. Quitinase. Celulase. Proteínas Cry. 


\section{References}

ASHLEY, T. R. et al. The fall armyworm: a bibliography. Florida Entomologist, [S.l.], v. 72, p. 152-200. 1989.

BANKA, R. R. et al. Fibril formation from cellulose by a novel protein from Trichoderma reesei: a non-hydrolytic cellulolytic component? World Journal of Microbiology and Biotechnology, [S.1.], v. 14, p. 551-558, 1998.

BOISSET, C. et al. Imaging the enzymatic digestion of bacterial cellulose ribbons reveals the and character of the cellobiohydrolase Cel6A from Humicola insolens and its mode of synergy with cellobiohydrolase Cel7A. Applied and Environmental Microbiology, [S.1.], v. 66, p. 1444-1452. 2000.

DESHPANDE, M. V. Enzymatic degradation of chitin \& its biological applications. J. Journal of Scientific \& Industrial Research, [S.1.], v. 45, p. 273-281. 1986.

GOODAY, G. W. Diversity of roles for chitinases in nature. In: ZAKARIA, M. B., WAN MUDA, W. M.; ABDULLAH, M. P., (Ed.). Chitin and chitosan. Malasya: Penerbit University Kebangsaan, 1995.

HENRISSAT, B. Cellulases and their interaction with cellulose. Cellulose, [S.l.], v. 1, p. 169-196, 1994.

KLEMAN-LEYER, K. et al. Changes in molecular size distribution of cellulose during attack by white rot and brown rot fungi. Applied and Environmental Microbiology, [S.1.], v. 58, p.1266-1270, 1992.

KLEMAN-LEYER, K. et al. Changes in molecular size distribution of insoluble celluloses by the action of recombinant Cellulomonas fimi cellulases. Biochemistry Journal, [S.1.], v. 302, p. 463-469, 1994.

KLEMAN-LEYER, K. et al. The cellulase endoglucanase I and cellobiohydrolase II of Trichoderma reesei act synergistically to solubilize native cotton cellulose but not to decrease its molecular size. Applied and Environmental Microbiology, [S.l.], v. 62, p. 2883-2887, 1996.

KNOWLES, J. et al. Cellulase families and their genes. Trends Biotechnology, [S.1.], v. 5, p. 255-261, 1987.

KONGRUANG, S. et al. Quantitative analysis of cellulose-reducing ends. Biotechnology and Applied Biochemistry, [S.l.], v. 113/116, p. 213-231, 2004. 
10 Universitas: Ciências da Saúde, Brasília, v. 7, n. 1, p. 1-12, 2009

Vinícius F. Dumas, Clarissa S. Goldenberg, Érica S. Martins, Lílian B. Praça,

Paulo R. Queiroz, Rose G. Monnerat, Francislete R. Melo

KUO, J., FOX, E., MACDONALD, S. Sigmastat: statistical software for working scientists. Users manual. San Francisco: Jandel ScientiWc, 1992.

LORENCE, A. et al. Delta-endotoxins induce cation channels in Spodoptera frugiperda brush border membranes in suspension and in planar lipid bilayers. FEBS Letters, [S.1.], v. 6, n. 3, p. 217-222, 1995.

LYND, L. R. et al. Microbial cellulose utilization: fundamentals and biotechnology. Microbiology and Molecular Biology Reviews, [S.1.], v. 66, p. 506-577, 2002.

MAAGD, R. A. de et al. Structure, diversity, and evolution of protein toxins from spore-forming entomopathogenic bacteria. Annual Review of Genetics, [S.l.], v. 37, p. 409-433. 2003.

MARTINS, E. S. et al. Characterization of Bacillus thuringiensis isolates toxic to cotton boll weevil (Anthonomus grandis). Biological Control, [S.1.], v. 40, p. 65-68, 2007.

MAWADZA, C. et al. Purification and characterization of cellulases produced by two Bacillus strains. Journal of Biotechnology, [S.l.], v. 13, n. 3, p. 177-187, 2000.

MONNERAT, R. G.; BRAVO, A. Proteínas bioinseticidas produzidas pela bactéria Bacillus thuringiensis: modo de ação e resistência. In: MELO, I. S.; AZEVEDO, J. L. (Ed.). Controle Biológico. Jaguariúna, SP: Embrapa, 2000. v. 3.

MONNERAT, R.G. et al. Screening of Bacillus thuringiensis isolates active against Spodoptera frugiperda, Plutella xylostella and Anticarsia gemmatalis. Biological Control, [S.1.], v. 41, p. 291-295, 2007.

PATIL, R. S.; GHORMADE, V.; DESHPANDE, M. V. Chitinolytic enzymes: an exploration. Enzyme and Microbial Technol., [S.1.], v. 26, p. 473-483, 2000.

PORTILLO, H. E. et al. Langosta: a lepdopterous pest complex on sorghum and mayze in Honduras. Florida Entomologist, [S.1.], v. 74, p. 287-296, 1991.

PRIEST, F. G. Extracellular enzyme syntesis in the genus Bacillus. Archive of Bacteriological Reviews, [S.1.], v. 41, p. 711-753, 1977.

REGEV, A. et al. Synergistic activity of a Bacillus thuringiensis delta-endotoxin and a bacterial endochitinase against Spodoptera littoralis larvae. Applied and Environmental Microbiology, [S.1.], v. 62, n. 10, p. 3581-3586, 1996. 
REISSIG, J. et al. A modified colorimetric method for the estimation of $\mathrm{N}$-acetylamino sugars. The Journal of Biological Chemistry, [S.l.], v. 217, p. 959966, 1955.

SAMPSON, M. N.; GOODWAY, G. W. Involvement of chitinases of Bacillus thuringiensis during pathogenesis in insects. Microbiology, [S.1.], v.144, p. 21892194, 1998.

SHAIKH, S. A. et al. Chitinolytic enzymes: their contribution to basic and applied research. World Journal of Microbiology and Biotechnology, [S.l.], v. 9, p. 468475, 1993.

SIRICHOTPAKORN, N. et al. Coexpression of Chitinase and the cry11Aa1 Toxin Genes in Bacillus thuringiensis serovar israelensis. Journal of Invertebrate Pathology, [S.1.], v. 78, p. 160-169, 2001.

SMIRNOFF, W. A. Confirmation experimentales du potential du complexe Bacillus thuringiensis chitinase pour la repression de al tordeuse des bourgeons de espirette Choristoneura fumiferana. Canadian Entomologist, [S.1.], v. 109, n. 351-358, 1997.

TEERI, T. T. Crystalline cellulose degradation: insights into the function of cellobiohydrolases. Trends in Biotechnology, [S.1.], v. 15, p. 160-167, 1997.

TERRA, R. W. The origens and fubction of the insect peritrophic membrane and peritrophic gel. Archives of Insect Biochemistry and Physiology, [S.l.], v. 47, p. 47-61, 2001.

THAMTHIANKUL, S. et al. Chitinase from Bacillus thuringiensis subsp. Pakistani. Applied Microbiology and Biotechnology, [S.l.], v. 56, n. 3/4, p. 395-401, 2001

WANG, W. et al. Function of a low molecular weight peptide from Trichoderma pseudokoningii S38 during cellulose biodegradation. Current Microbiology, [S.l.], v. 46, p. 371-379, 2003.

WATANABE, T. et al. Domain structures and functions of bacteral chitinases. In: MUZZARELli, R. A. A. (Ed.). Chitin Enzymology. Ancona: Eur. Chitin Soc., 1993.

WOOD, T. M.; GARCIA-CAMPAYO V. Enzymology of cellulose degradation. Biodegradation, [S.1.], v. 1, p. 147-161, 1990. 
12 Universitas: Ciências da Saúde, Brasília, v. 7, n. 1, p. 1-12, 2009

Vinícius F. Dumas, Clarissa S. Goldenberg, Érica S. Martins, Lílian B. Praça,

Paulo R. Queiroz, Rose G. Monnerat, Francislete R. Melo

YOUSTEN, A. A. Bacillus sphaericus: Microbiological factors related to its potencial as a mosquito larvicide. Biotechnology Progress, [S.l.], v. 3, p. 315-343, 1984.

ZHANG, Y-HP; LYND, L. R. Toward an aggregatedunderstanding of enzymatic hydrolysis of cellulose: noncomplexed cellulase systems. Biotechnology and Bioengineering, [S.1.], v. 88, p. 797-824, 2004.Keywords: Bacillus thuringiensis. Chitinase. Cellulase. Cry proteins. 